\title{
Institutionalization and Settlement of Neoshamanisms in Spain: The Case of the Valencian Country
}

\author{
Maria Albert Rodrigo ${ }^{1 *}$ \\ ${ }^{1}$ Dpt. Sociologia y Antropología Social, University of Valencia, SPAIN
}

*Corresponding Author: maria.albert@uv.es

Citation: Albert Rodrigo, M. (2017). Institutionalization and Settlement of Neoshamanisms in Spain: The Case of the Valencian Country, European Journal of Sociology and Anthropology, 2(2), 5. https://doi.org/10.20897/jcasc/81630

Published: December 30, 2017

\begin{abstract}
In this article, we explore the penetration of different shamanic currents in the new millennium in Spain, with a particular focus on the Region of Valencia. The traditions in this area differ from the shamanic traditions that had been previously adopted in two aspects: they are different shamanic currents and they follow their own settlement dynamics. By using a qualitative methodology based on a combination of thorough interviews and field observations, we have approached diverse neoshamanic manifestations in the years 2015, 2016 and 2017. We have used some of the interviews and observations of our field work. Our unit of analysis has been the Region of Valencia although the theory could be applied to the whole country. Besides, the information that circulates around websites and social media has been taken into account too. From the year 2005 on, new neo-shamanic currents have come to the Region of Valencia. That allows us to speak about a second phase in which the extension, institutionalization and settlement of the phenomenon occur together with a reconfiguration of the traditions that is shown in specific examples. All of this is shown through specific examples: the sakb'e, white way; the followers of Michel Harner and the Ayahuasca intake. The first two are centres/schools where training is given, that is, schools where the shaman's apprentice is trained in different techniques and trainings for a set period of time that leads to a degree that certificates the training has been completed. They are good examples of the process of institutionalization of the phenomenon. The third example illustrates how the ayahuasca intake is reconfigured through the case that is specifically presented in this article.
\end{abstract}

Keywords: spirituality, Shamanism, Neo Shamanism, New Spiritualties, Valencian Country

\section{INTRODUCTION}

Taking the perspective of the social sciences into account, particularly the perspective of anthropology, the aim of the present article is to explain by means of shamanism extremely complex and heterogeneous phenomena that are present in very different and distant societies. Originally created as an analytical tool for comparing similar realities, shamanism has become one of the most controversial topics for ethnologists and anthropologists (Caicedo, 2007:116) because the alleged universality of the shamanic phenomenon suggests that diverse cultural practices are conceived equally, without reflecting the original indigenous features. Currently, there are many senses and meanings that have turned the term shamanism into a sort of elusive nebula, permanently calling into question the image that has been developed of the being and the indigenous worlds (Caicedo, 2007:115).

We agree with Porras that although shamanism is an ambiguous concept, it currently encompasses diverse practices and conceptions based on specific power relationships that some human beings have (as privileged intermediaries) with the natural world, the supernatural sphere and the different societies and cultures to which 
they belong (Porras Carrillo, 2003:1). However, it is necessary to distinguish shamanism from neoshamanism; the latter involves "those shamanic practices performed outside the traditional context that can barely fulfil the social and collective functions for which the shaman is designated" (Prat, 2014: 28). This is what happens in the Western World and is supported by the topics included in this article.

Recent decades have seen the emergence of groups that can be understood as indicators of a new religious conscience, considered a large-scale phenomenon questioning the cultural development of our society and including cultural, creative and experimentation movements characterised by great heterogeneity (Albert and Hernández, 2014). Their main figures are what we can call physical-psycho-spiritual movements. They are integrated by very different people who share a dissatisfaction with the world they live in and look for alternatives at physical, psychological and spiritual levels (Albert, 2017a). Everything occurs in an increasingly globalised context within what is known as "the reenchantment of the world" (Maffesoli, 2009). This encompasses a wide arrangement of vague meanings and uncertain boundaries with very different expressions. Among these, the renowned "new age" must be highlighted. It goes back to the 1960s, with successive phases and transformations. In addition, it is what Heelas et al. (2005) call a "holistic milieu" with regard to spiritual and therapeutic practices.

Given these developments, the focus in the following pages will be on the different shamanic currents that have come to Spain ${ }^{1}$, paying particular attention to their institutionalisation and settlement process. This will be presented as a second phase since it shows notable differences when compared to the first currents that came to the country in the late 1980s, which we have already examined in previous papers (Albert, 2017b). We have approached diverse neoshamanic manifestations in the years 2015, 2016 and 2017 by using a qualitative methodology based on a combination of thorough interviews and field observations. For this article, we have used some of the interviews and observations from our field work during those years of research. Five thorough interviews have been selected; they include the testimonies of three men and two women aged between 42 and 52 who are renowned individuals within the shamanic sphere. The interviews occurred at their homes, at the places where they organise private consultations, or during shamanic work groups. In addition, four field surveys conducted within different ethnographic contexts (a 5-day-long shamanic retreat, a shamanic journey workshop and two talks presenting shamanic teachings) were used. Our unit of analysis was the Region of Valencia, though it is difficult to set borders in the networks making up this neo-esoteric circuit (also known as new age, mystical or alternative, depending on the author) that can be broadly applied to the whole country. Furthermore, the information that circulates around websites and social media has been considered since it is important for the configuration and development of the phenomenon. By first giving specific examples, the main features of the described neoshamanic currents will be explained within the framework of the contemporary spiritualities expressed in this reenchantment process in the Western World. We can mention some anthropological works that have been conducted in southern Europe with regard to contemporary spiritualities. In France, Fedele (2008) describes the beliefs and ritual practices that run through "the pilgrims of Mary Magdalene" and that are clearly influenced by the movement of feminist spirituality. Lombardi (2011) focuses on how the awakening of the indigenous question on the world stage grants a position of visibility to neo-shamanism. In Spain, Cornejo and Blázquez (2013) focus on the expansion of New Age individual spirituality as well as on its influence on complementary and alternative medicine. This expansion means the convergence of two areas historically divorced by Modernity (health and spirituality) and therefore the emergence of a new cultural landscape. In addition, Albert and Hernández (2014) analyse the global emergence of a new holistic, transversal and personal spirituality that is generating new coordinates related to the religious. Roussou (2013) describes the practices of New Age and how the eastern spiritual orientation challenges the exclusivity of Orthodoxy as the autochthonous religion in contemporary Greece. Roussou (2015) explains how Portuguese religiosity is going through a process of individualisation, where new forms of spirituality have become an active part of people's everyday religious practice.

\section{THE CREATION OF SHAMANIC SCHOOLS IN THE NEW MILLENNIUM WITHIN THE REGION OF VALENCIA}

The shamanic phenomenon has rarely been studied within the Spanish context, although it is possible to track some works (Úso, 2001; López, 2016; Albert, 2017b), particularly within the regional scope in Catalonia (Prat et al, 2012; Prat, 2014; Apud and Romani, 2017) and in Andalusia (Lagunas and Bozano, 2014; Bozano, 2015). The Concheros dance is based on the sacred ancestral dances of the Aztecan people. It came from Mexico by the hand of Emilio Fiel in the late 1980s. First, small groups interested in the shamanic field, the awakening of global awareness and the learning of spiritual teachings from indigenous and mestizo cultures in America were created in

${ }^{1}$ This article is part of the project called "Ethnic Tourism and New Age Rituals in the Highlands of Chiapas, Mexico" (GV/2015/038). 
Spain. They were known as Quetzalcóat ${ }^{2}$ clans. These would later give way to the Gaia groups and the Chrisgaia School. Since its creation in the first decade of the 21 st century, the school has focused on the evolution of the collective awareness. To that end, it offers an induction training that lasts two and a half years. Anyone who completes its 20 weekend encounters, 8 intensive sessions and 2 retreats can become one of the school's instructors. The school participates in transnational meetings, collective ceremonies, publications, conferences, experimental projects and particularly in the Mesa General de la Cruz Espiral de Nuestro Señor Santiago de Hispania (General Committee of the Spiral Cross of Lord Santiago of Hispania), which encompasses 15 regional committees spread throughout several Spanish provinces. Valencia has hosted one of them since the $1990 \mathrm{~s}^{3}$. In the 1990s, the Red Road -another shamanic current- also arrived in Spain. The Region of Valencia was an important enclave for its settlement, although it is also present in other Spanish regions such as the Basque Country, Catalonia and Aragon ${ }^{4}$. It is a new liturgical design created by Aurelio Díaz Tekpankalli and Alfonso Pérez Espíndola. These two Mexican men were able to combine rituals from different native cultures settled throughout the American continent, from North, Central and South America, and joined them into a panindigenist syncretism. Ayahuasca started coming to Spain regularly in the very late 1980s as well as the other two aforementioned currents. As López indicates, its use occurs in a context where participants are psychotherapists - mainly psychiatrists and psychologists - who have included the use of psychoactive substances within their personal and professional training (López, 2016:232). Thus, they should not be considered shamanic currents until the subsequent developments that took place after the entrance of the ayahuasca High-Amazonian shamanism.

Therefore, we will see them living together with new traditions that are developing gradually and that did not exist until that moment. Below we will see how from the year 2005 on, neoshamanism has clearly settled in the Region of Valencia. In addition, the penetration of new currents will be explained. It is worth mentioning that in other Spanish areas, such as Madrid and Catalonia, this occurred a few years earlier, approximately ${ }^{5}$ from the year 2000. The focus will be on three different neoshamanic currents with the purpose of illustrating the process that occurs in the second phase of neoshamanic currents coming to Spain. This phase has its own characteristics and it is different from the first phase, as studied in other works (Albert, 2017b).

\section{The Sakb'e, White Way, Way of Knowledge}

In several Mayan languages "Sak" means white. It can also be translated as something that is handmade. "B'e" means way, path or road. In ancient times, they were known as Sakb'eob', which is the plural form of Sakb'e. These were the stucco-paved roads that connected ceremonial architectural complexes. The Sakb'e essentially had a sacred function as they were used for processions, pilgrimages and other ritual activities. Thus, the Sakb'e is one of the names used today to refer to the traditional path of Mayan spirituality (Romera, 2017). One of our interviewees states the following:

“...Yes, the Sakb'e, the white road. Yes, that is how they refer to the Mayan sphere, because it means everything and spirituality is part of that whole Mayan sphere...." (Interview 06/2017)

The most likely possibility is that this term appeared in Guatemala during the emergence of the Mayan movement that occurred at the end of the 20th century. In any case, it is a symbolic expression that encapsulates the elements involved in the traditional Mayan way of self-knowledge and human development. These elements are based on the belief that everything is sacred for the 'aq'be walker since all things and creatures have a Being and are alive; they are complete and whole and therefore fully and entirely fulfil their function. This shows a way back to nature (Kajulew), a return path to living its inherent sacredness. It reveals that the whole human potential can only be recognised and duly developed when based on the restoration of the deep and subtle ties that bind us to the earth and its creatures (Romera, 2017).

This way came to the region of Valencia by Antonio 6 , who travelled to Mexico for personal reasons. There, a few years later, he acquired the "Sobada technique" performed by Mayan indigenous people,

“... and I met a person who transmitted to me the way of working that I took with me. It is called the Sakb'e method....” (Interview 10/2015).

It should be noted that indigenous authenticity based on a Mayan past is characterised by the preservation of the autochthonous Tzotzil language; the typical dress made of lamb's wool, which is considered a sacred animal; the Mesoamerican agriculture that combines corn, beans and pumpkins; the traditional diet based on handmade

\footnotetext{
2 (Field notes -Mar 2015-).

3 (Field notes -Abr 2016-).

4 (Field notes -Jul 2016-).

5 (Field notes -Feb 2017-).

${ }^{6}$ To preserve privacy, a fictitious name is used in all of the cases presented.
}

(C) 2017 by Author/s 
firewood-cooked corn tortillas; the traditional construction of adobe houses; and the numerous festivities and rituals honouring Catholic saints that hide Mayan beliefs of supernatural beings (Bayona, 2015:42). When Antonio returned to Spain in 2005, he settled in the surroundings of Valencia and opened a centre-school, which, according to him, is

“...a meeting point created to facilitate everybody's journey of knowledge through the Indigenous Wisdom. Its main source to understand and work with the Energy from the Heart, the Sakb'e Mayan method, as well as different sources of indigenous traditions...." (Interview 10/2015).

Different actions are carried out in this multi-purpose space, each focused on the audience to which it is directed. On the one hand, some activities are organised periodically: courses and workshops, trainings in general in the school (courses ${ }^{7}$ for sakb'e therapists, shamanic alchemy, Mayan sakb'e, and initiation workshops ${ }^{8}$ to the sakb'e method, shamanic chants, etc.). On the other hand, there are private consultations and ceremonies, also organised periodically.

According to Antonio, the Sakb'e method achieves the creation of a vibrational state by means of the energetic history of the person. It allows for the discovery of emotions and the relationship with the body and the being of light. It is possible thanks to

“...the capacity of the Mayan people for developing the work and the dominion of the mental energy. That allowed knowing and using the energy like no other tradition. Apart from the link to the Universe, it was possible for them to achieve a special conception of the human being by means of the observation and the study of the sky and nature. It made it possible for them to know that it is just an energy projection and that it does not live independently and in isolation from the other beings. On the contrary, it is a relationship of interdependence where the energy turns and comes from the solar energy, $\mathrm{K}^{\prime}$ inan, the spirit...." (Interview 10/2015)

The Maya have also passed their astrological calendar on to us. It is a knowledge taught in courses and workshops - sometimes as teachings and sometimes as a personal consultation - in different centres or schools in the cities and in some villages in the Region of Valencia. Luis ${ }^{9}$ from Madrid recently visited the region after travelling around Latin America. He lived in Guatemala for nine years and was linked to rural health projects in local organisations that followed Mayan ancestral knowledge. He became an Aj Qij, or time counter, a special public service that entailed the use of fire, astrology and the oracle of seeds:

“...the specialists that I found in Guatemala are fertility and gestation midwives, birth and puerperium midwives, 'ahumadores', spirit callers or Aj Qij (meaning "those who come from the fire"). There are also bone healers, plant healers and those who extract rotten or black blood from people..." [...] "...little by little, I started to share what I had learned in Guatemala with the reading of the personal Mayan letter and celebrating ceremonies in the mountains. Like that, little by little...." (Interview 06/2017)

After returning to Spain in 2009, he visited several cities in Spain to teach and share his knowledge.

\section{Followers of Michael Harner's school}

Founding member José and his wife Marta own a centre that offers a training they call practical shamanism. This is a specific training for therapists and healers where different workshops are held. José learned from Martin Duffy in the Foundation for Shamanic Studies by Michael Harner in Ireland. This school is a world leader on shamanistic studies. Harner, its founder, has become a renowned figure and international authority and has had an enormous influence in the spread of shamanism around the world after his school's large-scale proliferation. By means of the Foundation ${ }^{10}$, he has developed a transcultural shamanism, which he refers to as a "shamanic core." It includes what its founder considers the universal and common traits of shamanism. Therefore, the principles of transcultural shamanism are not bound to any cultural group. It is hoped that the Western World can learn from shamanism and turn it into a way to reacquire access to its legitimate spiritual legacy with the aim of discovering its own resources, transforming people's lives and learning how to help others.

José lived in Ireland for five years and worked with healers who had shamanic and druidic training. Previously, he had travelled around several American countries where he had been in touch with the shamanic world. The most interesting thing is the fact that he was able to create his own school. He has been teaching his own shamanic

\footnotetext{
${ }^{7}$ With a duration of $10-11$ months.

${ }^{8}$ With a duration of between 4 and 12 hours that is often held at the weekend.

${ }_{9}^{9}$ Since February 2017, he has been in individual consultations and giving a training in a Valencian centre.

${ }^{10}$ In Spain, Alicia Luengas Gates is its representative. She is based in Barcelona and teaches advanced shamanism training courses (with a duration of three years) as well as training workshops.
} 
training since the first decade of the new millennium in the Region of Valencia, and he offers consultations and workshops.

“... Firstly, I was giving consultations for two years, more or less ... providing consultation. And at that time I was thinking about bringing Martin Duffy from Ireland so he could teach the training, but it didn't flow. There was something there that... wasn't working. Until I realised it was me. I'm sorry. The one who had to teach it. I simply didn't dare; I wasn't confident enough. But in two years I started to... design it. By then I had also received training in transpersonal therapy in Madrid. It was in a school... in the Institute.... It was called the Transpersonal School, and I was with José María Doria. There, I also learned to work with the expanded states of awareness through breathing. They call it holorenic, but it is like a holotropic breathwork, Stan Grofs...." (Interview 09/15)

From his private consultation, and especially from his school, he developed shamanism as a tool for selfknowledge and personal growth. The self-knowledge way, according to José, takes us closer to the spiritual part. In many cases, this way requires us to discover it, which inevitably has a therapeutic effect. In this sense, José supports the idea of a possible approach of medicine and shamanism,

“... it is a very simple tool. It is very effective and accessible for everybody, and it is very recommendable as... a personal tool. Something that I like is that once you show the tool, you can make your own shamanic journeys, having your masters in the non-ordinary reality. I think that it is something that must be taken advantage of because it is part of our potential. It is everywhere and everything... it is in all human beings. And I think that it would be very interesting for the citizens to have access to this tool and that it could also be included in Social Security, where it could work together with the allopathic medicine...." (Interview 09/15)

However, the healing dimension goes beyond the physical and psychological aspects. The social dimension must be highlighted as well-the need to establish relations with other spheres such as the spiritual dimension. These allow us to do it more sincerely, in a more "real" manner. In this way, we also heal collectively.

“...Generally, they come back, sooner or later. As they have that contact, they come several times, then they don't, and then in four months they come again ... In truth, they come to me like... they do not go to mass any more, they do not have the contact with spirituality, but they realise that it is like that space where you connect, where there is a bit of growth, of knowledge on what our mind is, how it works and the contact with the spiritual...." (Interview 09/2015)

In that sense, it is very interesting to reflect upon what he calls urban shamanism. Although it may seem a contradiction with regard to nature contact, it is essential for the shamanic practice. He understands that the true challenge at present is being able to practice and apply it in the large cities where the majority of people in the Western World live.

What seems even more relevant in this case is that they have been able to establish a training programme called Training on Contemporary Practical Shamanism. It grants a certificate to the candidate and includes an intensive course of seven face-to-face days, supervised practices, four months of post-course follow-up and three on-line tutorials ${ }^{11}$. In addition, there are shorter workshops, such as How to Become an Urban Shaman; Awake Your Inner Shaman; and The Shaman Apprentice, Shamanic Age Regression. In just a few years, hundreds of shaman candidates have attended the school.

\section{Ayahuasca}

Ayahuasca is a psychoactive beverage traditionally used by indigenous and mestizo populations in the Amazon basin. The beverage usually consists of a blend of two plants, Banisteriopsis caapi and Psychotria viridis, although they may be substituted with other plants (Apud and Romani, 2017: 28). The first ayahuasca ceremonies held in Spain were led by Santo Daime members within the Seekers After Truth (SAT) psychotherapeutic training programme led by psychiatrist Claudio Naranjo. In the late 1980s in Spain, there existed an undetermined but far from negligible number of psychotherapists (Almendro, 2008) who worked with ayahuasca, anahuascas and other psychoactive substances such as LSD or MDMA. These included psychotherapists in general, mainly psychiatrists and psychologists (López, 2016:232). Apud \& Romani indicate different orientations in the use of ayahuasca in their fieldwork. There is a link with actors from academia, whose contact with ayahuasca is a result of intellectual and/or therapeutic interest. However, there are also more pragmatic uses, as in the case of the Institute of Applied Amazonian Ethnopsychology, whose modus operandi is structured with a more therapeutic focus and rituals

\footnotetext{
${ }^{11}$ In 2018, it will be held for the 13th time.
} 
designed to support the patient's process with a dialogic interest between traditional medicines, all types of alternative medicines and modern medicine (Fernández and Fábregas, 2014). Other groups were created after their founders came into contact with ayahuasca on pilgrimages to South America. Some are spiritual seekers, whereas others set off to find a cure for a particular problem and returned as "wounded healers" (Apud and Romani, 2017:31). However, we are interested in considering ayahuasca within the shamanic practices that have been developed in Spain in the new millennium. They come from the Amazonian upper basin (López, 2016:157), but they are expressed in as many ways as the number of people who teach them since the barriers between the different uses are not always easy to define. The author mentions three High-Amazonian shamanic modalities: an alleged Pre-Hispanic shamanism; a shamanism practised by the mestizo population and that appeared halfway through the 19th century for rubber extraction; and a religious cabocla-influenced shamanism that appeared in the 1930s. This temporary arrangement does not necessarily imply an evolutionary order (López, 2016:170). The following is the case of 55-year-old Carolina, a female psychologist, a profession that she practised in private consultation. In the late 1990s, she tried ayahuasca from the SAT:

"...I was there at that moment in the training with Claudio Naranjo at his school, the SAT, right? And I asked him, I told him, 'Look! I don't think this is going forward with the psychotherapy. I am blocked here, and with my disease... I don't think I can solve it, right?' And then he recommended me to take ayahuasca...." (Interview 01/2016)

After this first experience, which turned out to be very powerful, she looked for other sources, and a friend told her that a shaman was coming from Ecuador and that an ayahuasca take had been organised. She hurried to join, and she later described it as a "really powerful, bone-crushing experience."

“...I took it for the first time with this shaman, and I had a really powerful, bone-crushing experience, right? As a process of death and rebirth, right? And then in that moment, the shaman who was leading the ceremony told me that he was Shuar, from the Shuar ethnic group in Ecuador. He told me that they, the Shuar, believe that the ayahuasca goes into you in that special way, right? It crushes you, completely, that is why they believe that you have to develop yourself as a shaman...." (Interview 01/2016)

With the passing of time, the experience turned out to be very strong. She took ayahuasca on an ongoing basis, more or less once a month, moving around Spain depending on the offers she could find.

"....well, with what I could at that time in Spain, sometimes in the Santo Daime or where I could find it $[\ldots]$ looking for a place where I could find ceremonies. I went to Seville a lot; there was a group there, and I had some friends there in the Santo Daime. I went to Madrid too, where they have the main church, and, anyway, I went wherever I could [...] there wasn't a lot at that time, there was very little...." (Interview 01/2016)

At the same time, she continued participating in the takes the Ecuadorian shaman organised approximately every six months. He then started organising groups in Murcia, where she was living at the time, and she finally began going to Ecuador to be introduced by the shaman masters and "receive the power transmission." She then began going every summer for the initiations and to follow the prescribed "diets" and other necessary actions until she felt ready to conduct the takes herself. A few years later, in January 2013, she went with her partner to Ecuador, where she lived close to her master with the purpose of collaborating and participating in the ceremonies, consultations and works he performed.

“...my partner and me lived there. Every week - Tuesday and Friday - Sebastián organised purification ceremonies for his patients to heal and we were there with him, taking and healing patients...," (Interview 01/2016)

Moreover, Carolina began taking groups from Spain for healing and learning. After that she visited Spain twice a year to celebrate ceremonies, and perform consultations and workshops. She had an establishment where she performed these type of works nearby Valencia.

“...I also took groups from there to Spain. There were people who went there to undertake physical, psychological and spiritual healings but also to perform some initiations and that's how we continued, you know...." (Interview 01/16)

In the long learning process undergone by Carolina, we can seen how her disease drove her to taking ayahuasca. In addition, the positive results she obtained encouraged her to continue. She talked about this powerful process 
and commented on the steps she took to become a medicine woman ${ }^{12}$. She currently lives between Spain and Ecuador and is mainly devoted to officiating ceremonies with ayahuasca. She understands them as a very powerful healing tool physically, psychologically and spiritually.

\section{CHARACTERISTICS OF THE SECOND PHASE, INSTITUTIONALISATION AND SETTLING}

So far, we have seen how the new millennium has looked upon the arrival of shamanic currents from people who have travelled to Latin countries and who later settled in the Region of Valencia. We have presented the most relevant cases of those who settled there by considering the high degree of institutionalisation they have achieved in their centres/schools and the number of people they draw. In two of the presented cases, Antonio and José with his partner Marta have created a training that grants a non-official certificate ${ }^{13}$ of the shamanic knowledge acquired. In fact, they have established a neoshamanic academy in Valencia that has hosted more than a thousand people in recent years. These people add the training to their curriculum and start using these shamanic tools for themselves and to help others. In regard to helping others, it is worth mentioning that many people are dedicated to alternative therapies (for example, family constellations ${ }^{14}$ or rebirthing). One example is a therapist devoted to family constellations who, after acquiring this shamanic knowledge, advertises her therapy sessions as shamanic constellations in which she has introduced the drum and the rattle ${ }^{15}$. This is a clear example of neoshamanic reconfiguration applied to family constellations. It can be seen in as many forms as neoshamans exist since every one of them creates his/her own "menu" with different characteristics related to therapy, healing, personal growth or the expansion of consciousness, depending on the case. In addition, they have acquired a new, higher level of articulation and significant visibility by means of the associations they have created.

In the case of Antonio, he is linked to the Suhuy Tu' Kul' Association, which is connected to the League of Mayan Communities and whose aim is to strengthen the cultures and traditions of indigenous peoples. The purpose of the association is to facilitate the journey of those who seek an encounter with this ancestral wisdom, "trying to preserve the indigenous knowledge and traditions." José and Marta are linked to the Spanish Association of Shamanic Studies (AEECH), which basically consists of people who have attended its school and have the aim of spreading the knowledge to society. Both associations, headquartered in Valencia, have collaborated in joint activities such as the one they organised in November 2016, to which they invited the director of the Hijos de la Tierra ${ }^{16}$ documentary. After screening the film, they celebrated a round table with great audience participation that ended with a drum session ${ }^{17}$. They also celebrated an event in February 2017 in the Sagunt Roman Theatre where they offered a free workshop called "Chants of the heart and American native culture" with Vernon Foster ${ }^{18}$, a renowned American shaman visiting Spain. These centres/schools have become a referent particularly in the Region of Valencia ${ }^{19}$. However, they receive people from everywhere because they have a great capacity for mobilisation.

In this sense, it is important to note that a rescue of the indigenous and shamanism is taking place from the neo-esoteric circuits ${ }^{20}$ circulating around the world. In the Western world, they are articulated through the aforementioned centres/schools offering alternative, integral, holistic therapies. This can be seen in the case of Luis, $\mathrm{Aj} \mathrm{Qij}$, who shares teachings acquired from the Maya in courses and workshops, sometimes as teachings and sometimes as a personal consultation. It is also worth mentioning that the Mayan features are expressed in those circuits as a syncretism using contemporary spiritualities and their own terms. In this regard, we can note some terms from Antonio's discourse: "energy," "vibrational state," "being of light." Thus, the increasing demand within the world's neo-esoteric circuits gives strength to the values of the indigenous since its shamanic dimension acquires a sense that had not been "seen" or "understood" in the Western world until recent decades. The question arises: why now? Due to the disaffection and the process of searching for meaning in the Western world, the spiritual dimension of the indigenous worlds, which has been labelled shamanism by the Western world, assumes an explanatory framework that can be added to three processes being currently developed. First, globalisation

\footnotetext{
12 As she'd rather be called.

13 As is the case in many other alternative therapy trainings in Spain.

${ }^{14}$ It is a systemic method developed by German Bert Hellinger that configures family systems with the help of persons who represent the family members. This configuration allows seeing and understanding the person as well as the family system and the harmful unconscious implications.

15 (Field notes -Febr 2017-).

16 About the curative capacities of plants and their ancestral knowledge, winner of a Goya award.

17 Tickets were sold out; the hall was crowded. (Field notes -Nov 2016-).

18 Indio Klamath/Modoc, raised with the lakota and the Ojibway, studied psychology, political science and theology in the University of

Minnesota/St. Paul. He offers workshops, talks and healings across the USA, Brazil, Japan and Europe.

19 (Field notes -Febr 2017-).

${ }^{20}$ Multiple terms have been used to refer to these circuits depending on the author, as esoteric, new age or alternative.
} 
facilitates the arrival and the constant exchange of knowledge and practices. Second, due to the intense heritagisation process in response to the multiple rapid changes of modernity, the preservation of ancestral practices and knowledge becomes critical. Third, the awakening of new spirituality formulas, which started in the 1970s with the counterculture and hippie movements, were followed by the New Age and its diverse developments within the framework of the contemporary spiritualities expressed in this process of reenchantment of the Western world.

In addition, there has been a high degree of penetration of "ayahuasca takes." The number of people conducting ayahuasca ceremonies in Spain is unknown. The estimate is approximately 70 people conducting sessions regularly in Spain and approximately 10 people visiting Spain sporadically (López, 2016:227). Although we have not taken a census, in our fieldwork, exponential growth is observed in the last years for those figures. We have presented an example ${ }^{21}$ of the blurry borders and the multiple uses of ayahuasca in Spain. Carolina, a psychologist by trade, not only entered this therapeutic option but also participated in ceremonies held in Santo Daime from a religious perspective. At the same time, she continued mainly learning from an Ecuadorian shaman. She even left her profession and went to Ecuador to become a shaman and to fully devote her time to it after undergoing diets and initiations for years. Thus, her offer comprises the different sources from which she has learned, highlighting the healing dimension:

"...the important thing is that she is a healer; therefore, she is a therapist, a spiritual therapist, because everything heals: the organic, the emotional, the spiritual, everything....” (Interview 01/16)

Furthermore, the Platform for the Defence of the Ayahuasca (PDA) was born. It was created on the occasion of Alberto Varela's detention at the end of 2008 by those who conducted ayahuasca works in Spain when he was about to begin an ayahuasca session. The use of this plant is not regulated in Spain. After a process that lasted almost three years, in which the Eleusis Association had a main role, this association, working in the national sphere, officially came into existence. The PDA's objectives are the creation of a legal framework, becoming an advisory body, legitimating the traditional and religious use of the ayahuasca and raising awareness about ayahuasca in Spain by respecting human rights, promoting investigation and, in particular, defending the application of an ethical code created by the PDA itself.

Nonetheless, we should not forget the native shamans who visit us periodically to meet the growing demand by offering their services and knowledge. As an example among many, a "Ceremony of the granny, Yaga Florida, the heart's medicine" was held in June 2017 by visiting Native American shamans. Another Peruvian shaman will be paying us a visit. She claims to "belong to a native-Andean lineage tradition with full knowledge of the sacred medicinal plants," and she will be conducting several sessions during summer solstice week in the Region of Valencia. She will also offer two concerts of icaro chants.

Finally, it should be stated that the male presence has been larger within the shamanic world. López (2016), in his doctoral thesis on ayahuasca shamanic practices, notes that "in Spain, like in the Upper Amazon, the presence of female shamans is rather rare." However, in light of the examples shown, that tendency seems to be changing. Like Colpron (2005), we also wonder whether the outlook presented in the literature specialised in female shamanism is rare or unimportant, if it is due to a thorough investigation of the matter, or if it reflects a lack of interest by Western researchers.

\section{CONCLUSIONS}

From the year 2005, new neo-shamanic currents have come to the Region of Valencia. In this article, we have focused on the Sakb'e, or wisdom way, the practical core shamanism course of Michael Harner's school and ayahuasca intake as examples of the traditions that have come to and settled in the region. The first two are centres/schools where shaman's apprentices are trained in different techniques and learnings for a set period of time that leads to a degree certifying the training has been completed, regardless of the fact that it is unofficial. In addition, they are linked to associations that embrace many of the new people entering the world of shamanism, many of whom have received their teachings. They are structured with a superior level of organisation that facilitates the arrangement of joint events and a higher level of visibility. In addition, the importance of sociability must be highlighted for the groups that are formed year after year.

Due to its quantitative importance, we have presented a case among many of the possible examples of the people in charge of the ayahuasca takes in the Region of Valencia. This practice has also found greater articulation with the organisation of a national association. Furthermore, in the case that has been presented, the ceremonies

\footnotetext{
${ }^{21}$ We have come across several cases (psychologists, therapists or facilitators) that offer ayahuasca takes as an entheogen substance, which is not therefore burdened with these shamanic connotations.
} 
are conducted by a woman. This fact represents the change that is occurring in this field, which has traditionally been led by men.

\section{REFERENCES}

Albert Rodrigo, M. (2017a). La espiritualidad en movimiento. El enfoque espiritual como herramienta de cambio social, in S. López-Pavillard and R. Llera (coords.), Etnografiando prácticas espirituales: Sentido y compromiso frente a la utopia (pp. 30-42). Valencia: PUV.

Albert Rodrigo, M. (2017b). Neochamanismos en España. Retorno a las creencias ancestrales. ILU. Revista de Ciencias de las Religiones, 22, 9-27. https://doi.org/10.5209/ILUR.57406

Albert Rodrigo, M. and Hernández Martí, G. M. (2014). Los movimientos psico-espirituales en la modernidad globalizada. Una mirada desde la ciudad de Valencia. AIBR-Revista de Antropología Iberoamericana, 9(3), 273-296. https://doi.org/10.11156/aibr.090304

Almendro, M. (2008). Chamanismo. La vía de la mente nativa. Barcelona: Kairós.

Apud, I. and Romaní, O. (2017). Medicine, religion and ayahuasca in Catalonia. Considering ayahuasca networks from a medical anthropology perspective. International Journal of Drug Policy, 39, 28-36. https://doi.org/10.1016/j.drugpo.2016.07.011

Bayona Escat, E. (2015). Rituales indígenas y otras escenificaciones turísticas en los Altos de Chiapas. Nueva Antropología, XXXVIII, Enero-Junio, 31-50.

Bozano Herrero, J. I. (2015). Tecnochamanismo, raves y psicoactivos: el movimiento "psytrance" andalur. Editorial Academia Española.

Caicedo, A. (2007). Neochamanismos y modernidad. Lecturas sobre la emanciapación. Nomadas, 26, 114-127.

Colpron, A. M. (2005). Monopólio Masculino do Xamanismo Amazônico: O Contra-exemplo das Mulheres Xama Shipibo-conibo. Mana, 11(1), 95-128. https://doi.org/10.1590/S0104-93132005000100004

Cornejo Valle, M. and Blázquez Rodríguez, M. (2013). La convergencia de salud y espiritualidad en la sociedad postsecular. Las terapias alternativas y la constitución del ambiente holístico. Revista de Antropología Experimental, 13(2), 11-30.

Fedele, A (2008). El camino de María Magdalena. Un recorrido antropológico por la ruta de peregrinaje de la nueva espiritualidad. RVA.

Fernández X. and Fábregas J. M. (2014). Experience of Treatment with Ayahuasca for Drug Addiction in the Brazilian Amazon. In B. Labate and C. Cavnar (eds.), The Therapeutic Use of Ayahuasca (pp. 161-182). Springer, Berlin: Heidelberg. https://doi.org/10.1007/978-3-642-40426-9_10

Heelas, P. et al. (2005). The Spiritual Revolution. Why Religion is Giving Way to Spirituality. Oxford: Balckwell.

Lagunas Arias, D. and Bozzano Herrero, J. I. (2014). Neochamanismo y tecnoespiritualidad: el caso del movimiento trance en Andalucía. Revista Teknokultura, 11(1), 167-190.

Lombardi, D. (2011). Neo-chamanismo: el ritual transferido. XI Coloquio Internacional sobre Otopames 2009 Interdiscilinary Social Sciences-Anthropology Univ.

López Pavillard, S. (2016). La Vida como Proceso de Sanación. Prácticas Chamánicas del Alto Amazonas en torno a la Ayahuasca en España. Tesis Doctoral. Madrid: UCM.

Maffesoli, M. (2009). El reencantamiento del mundo. Una ética para nuestro tiempo. Buenos Aires: Dédalus Editores.

Porras Carrillo, E. (2003). Consideraciones sobre neochamanismo y chamanismo huichol. Gazeta de Antropología, 19, artículo 07.

Prat, J. (2014). Arquetipos y experiencias participantes en las periferias religiosas, in VVAA, Periferias, Fronteras y Diálogos. Una lectura antropológica de los retos de la sociedad actual (pp. 25-46). Tarragona: URV, 25-46.

Prat, J. et al. (2012). Els Nous Imaginaris Culturals. Espiritualitats orientals, terapies naturals $i$ sabers esoterics. Tarragona: URV.

Romera, J. C. (2017). Espiritualidad Maya. Consulted on-line at https:/ /www.culturaespiritualmaya.com/ [October, 2017]

Roussou, J. (2013). The new age of Greek Orthodoxy: Pluralizing Religiosity in everyday practice, in J. Mapril and R. Llera, Sites and Politics of Religious diversity in Southern Europe. Leiden, Boston: Brill. https://doi.org/10.1163/9789004255241_006

Roussou, J. (2015). From Socialization to Individualization: A New Challenge for Portuguese Religiosity. Italian Journal of Sociology of Education, 7(3), 89-112. https:// doi.org/10.14658/pupj-ijse-2015-3-4

Usó, J. C. (2001). Spanish Trip. La aventura psiquedélica en España. Barcelona: La Liebre de Marzo. 